\title{
PRODUCTION OF BIOGAS USING KITCHEN WASTE
}

\author{
Blesson $\mathbf{S}^{1}$, Ashish Ashok ${ }^{2}$, Arha Raghavan ${ }^{3}$, Divya P Gunagi ${ }^{4}$, Gautham Jeppu ${ }^{5}$, Rashmishree $\mathbf{K N}^{6}$ \\ 1,2,3,4,5,6 Depatrment of Civil Engineering, Sahyadri College of Engineering \& Management, Mangalore
}

\begin{abstract}
Biogas can give a clean, effectively controlled wellspring of renewable vitality from natural waste materials for a little work information, supplanting kindling or fossil energizes. Rich biomass from different organizations could a hotspot for methane generation where mix of waste treatment of vitality creation would be leverage. The biogas digester not only produce biogas but also its by-product can be utilized for other purpose like for agriculture. This study helps to determine the amount of biogas that can be liberate form two different digester of size 24lts and 18lts respectively. After which, it is compared with a normal LPG cylinder for the percentage of energy liberated by each.
\end{abstract}

Keywords: Kitchen Waste, Anaerobic Digestion, CH4 Production, Biogas Production.

\section{INTRODUCTION}

The lack of petroleum and coal fuel products leads to a fear throughout the world also the problem caused because of the combustion has lead to search of different energy sources which should also be a renewable source. Deforestation which is one of the major problems faced by developing countries like Indonesia, India, most of the people in these parts mainly depends on fuel-wood and charcoal for supply of fuel which requires the cutting of trees. Biogas as a source is different from other renewable sources because of its major characteristics of utilizing, controlling and gathering natural wastes and in the meantime delivering compost or by-products for use in agrarian and watering system. This type of renewable source of energy does not have any kind of topographical limitations or it require any advanced or high powered technology for energy production, it is also very easy and simple to utilize and apply it. The wastes from the kitchen are the organic components or materials which have a high calorific quantity or calorific value and also have high nutritive value. In this research two prototype digesters are feed with kitchen waste and their productivity is checked and then it is compared with the productivity of energy of LPG cylinder. The energy produced by cylinder and the prototype digester are compared on basis of their volume and for one month period production. At the beginning two digesters of size 24lts and 18lts respectively are taken and these are feed with cow dung by $25 \%$ the volume of digester in cow dung to water ratio $1: 2$. Then feeding of cow dung is continued by $0.2 \%$ the size of digesters till flammable gas is obtained. The organic food waste materials are feed and each day gas productions are checked.

\section{METHODOLOGY}

The following methodology is adopted in the project:

a. Construction of biogas-digester.

b. Collection of natural waste from the school nourishment court- Natural squanders like cooked nourishment waste or uncooked vegetables are gathered in basins. c. Feeding the natural waste to biogas digester-The waste is blended with water and made into slurry. This slurry is then encouraged into the digester through the bay. The slurry is left in the digester for extensive measure of time for processing. Institutionalization of parameters like $\mathrm{pH}$, temperature and introductory time prerequisite for biogas era and anaerobic processing is made.

d. Process occurring in the digester-Due to the nearness of anaerobic microscopic organisms and water in the slurry disintegration of slurry happens. Besides because of maturation, development of biogas happens which begins gathering in upper tank gave in the digester.

e. Collection of gas in upper tank of digester- The byresults of absorption are biogas and it gets gathered in upper tank of digester. As the gas is created the upper tank ascends to certain stature.

f. Removal of carbon dioxide-A scrubber is given having lime water in it to evacuate the $\mathrm{CO}_{2}$ present. Biogas created is made to course through the scrubber where $\mathrm{CO}_{2}$ is changed over into calcium carbonate.

g. Collection of effluents-As the creation of biogas increments, delivered gas applies a weight on the spent slurry. The spent slurry moves out through the outlet. The spent slurry is known as effluents.

h. Utilization of items- The slurry must be bolstered ceaselessly to acquire consistent supply of biogas.

i. Maintenance-The slurry must be bolstered ceaselessly to acquire consistent supply of gas.

\section{CASE STUDY OF BIOGAS DESIGN}

The estimation of biogas plant depends on upon the warm essentialness to be made. Since it is relied upon to supplant a bit of L P G gas, the imperativeness meet for 1 assembly of LPG is processed.

Comparability with the LPG is given as below:

Calorific LPG estimation is $50 \mathrm{MJ} / \mathrm{kg}$

1 chamber weight is $14.2 \mathrm{~kg}$

Thusly, Total vitality in one barrel is 14.2 multiply with 50 The Total vitality in one barrel is equal to $710 \mathrm{MJ}$ 
The essentialness which would be available in $1 \mathrm{~m} 3$ plant in 1 month. Biogas contains almost about $60 \%$ of methane.

Calorific quantity of the methane gas is $55 \mathrm{MJ} / \mathrm{kg}$

Thickness of $\mathrm{CH} 4$ at the NTP is equal to $0.668 \mathrm{~kg} /$ cubic meter

Thusly, Calorific estimation of the methane gas is equal to $55 \times 0.668$ is equal to $36.74 \mathrm{MJ} / \mathrm{m}^{3}$

Methane gas being the main real wellspring of warmth,

So Calorific estimation of the biogas is equal to

$0.6 * 36.74 \mathrm{MJ} / \mathrm{m}^{3}=22.044 \mathrm{MJ} /$ cubic meter

One plant of one cubic meter limit produces 0.7 cubic meter of the gas for every day.

Total vitality of $0.7 \mathrm{~m}^{3}$ of the biogas is $0.7 * 22$

Total vitality of $0.7 \mathrm{~m}^{3}$ of the biogas is $15.4 \mathrm{MJ}$

Expecting that the productivity of a biogas stove and LPG

Stove is the same

Vitality gave every month is $15.4 * 30$

Vitality gave every month is $462 \mathrm{MJ}$

Thusly a plant of biogas of one $\mathrm{m}^{3}$ limit is proportionate to a $65 \%$ of one LPG chamber for every months.

\section{THE FABRICATION AND FEEDING}

\subsection{Constant Feeding Digester}

The constant feeding digester is made out of steel, which is cylindrical in shape having a volume of 24 litres. It consists of one outlet, inlet and gas outlet. The inlet is fixed at the side bottom of the digester with an inclined cylindrical projection at an angle of $45^{\circ}$ with a diameter of the cylindrical projection as $7.5 \mathrm{~cm}$ and having a height of $45 \mathrm{~cm}$. The outlet is fixed at opposite side of the inlet at the side top which is about $25 \%$ of cylinder from top. The outlet is at a depth of $5 \mathrm{~cm}$ from the top of cylinder digester the length of the projection of the outlet is $28 \mathrm{~cm}$ and the diameter is $7.5 \mathrm{~cm}$. The gas outlet is having a height of $14 \mathrm{~cm}$ and having a diameter of $2 \mathrm{~cm}$ which is present at the top centre of the cylinder digester. The overall diameter of the steel cylinder is $27 \mathrm{~cm}$ and the height of the steel cylinder is $37.5 \mathrm{~cm}$. The outlet is provided with a valve so that even if the digester is filled more than $75 \%$, the effluent doesn't leak out. The gas outlet is provided with a valve having small nozzle. From this gas outlet the connection is sent to the balder (rubber tyre) which is placed above the level of the digester.

\subsection{Variable Feeding Digester}

The variable feeding digester is made out of plastic water can, which is cylindrical in shape having a volume of 18 litres. It too consists of one outlet, inlet and gas outlet. The inlet is fixed at the side bottom of the digester which is provided in $\mathrm{L}$ shape. The diameter of the inlet projection is $6 \mathrm{~cm}$ and the vertical projection is $39 \mathrm{~cm}$ and the horizontal projection is $22 \mathrm{~cm}$. The outlet is placed at opposite side of the inlet, which is at $9 \mathrm{~cm}$ from the top of the digester. The outlet diameter is $6 \mathrm{~cm}$ and the outlet projection length is $18 \mathrm{~cm}$. The gas outlet valve is present at the top centre of the water can having a diameter of $5 \mathrm{~cm}$. The outlet is provided with a valve so that even if the digester is filled more than the outlet limit, then the effluent doesn't leak out. The gas outlet valve is M-sealed to a fabric pipe of diameter $1.5 \mathrm{~cm}$. The pipe is then connected to another bladder which is placed above the level of digester.

\subsection{Lime Scrubber and Water Displacement Container}

The lime scrubber is nothing but a container or a small cylindrical chamberhaving a volume of 10litres. It consists of an inlet at the side bottom and outlet at the top centre. The pipes connected to this inlet and outlet are of diameter $1.5 \mathrm{~cm}$. The lime scrubber is filled with a solution of lime and water. For every 2 litres of water an approximate of $50 \mathrm{gms}$ of lime powder $\left(\mathrm{Ca}(\mathrm{OH})_{2}\right)$ is added. The lime is used to react with other constituents of the bio-gas so that the $\mathrm{CO}_{2}$ present in the biogas get eliminated since it reacts with the lime present in the solution. Hence it liberates pure methane gas into the water displacement chamber. The outlet of the lime scrubber is connected to inlet of water displacement container. The water displacement is a cylindrical container having a volume of 28litres. It consists of an inlet and outlet and a gas outlet. The inlet is placed at the side bottom of the container which is having a diameter of $1.5 \mathrm{~cm}$. The outlet is placed at the opposite side of the side bottom of the container. The outlet is in L shape having a diameter of $2.5 \mathrm{~cm}$ and vertical height of $30 \mathrm{~cm}$ and horizontal height of $13 \mathrm{~cm}$ at the bottom and horizontal height of $4 \mathrm{~cm}$ at the top of the outlet projection. The gas outlet valve is provided in line with or parallel to the water outlet projection. The amount of water which is displaced out of the water displacement chamber will be equal to the methane gas liberated while the experiment is conducted.

\subsection{Feeding Work Carried Out}

This project consists of 2 digesters. One is constant feed and the other is variable. Constant feeding has a volume of 24 litres while variable feed digester has the volume of 18 litres. Connections are in such a way that the constant feeding digester and variable feeding digester are connected to two different bladders. Here, in case of bladder we are using tire tubes.

The diameters of digesters are mentioned in above fabrication part. These are actually a prototype. There is a T connection provided for the tubes between the bladder and the digester. The $\mathrm{T}$ pipes are always kept closed and digester's gas liberating valve is always openso that, the gas is collected in the bladder. After the gas collected in bladder the $\mathrm{T}$ connection is opened and the digester valve is closed. The other end of the $\mathrm{T}$ connection is connected to a lime solution chamber from the bottom which is also called as scrubber. From the top of the scrubber a pipe connection is made to bottom of the chamber or container consisting of water. There is outlet provided for water in a $\mathrm{L}$ shape from the bottom. 


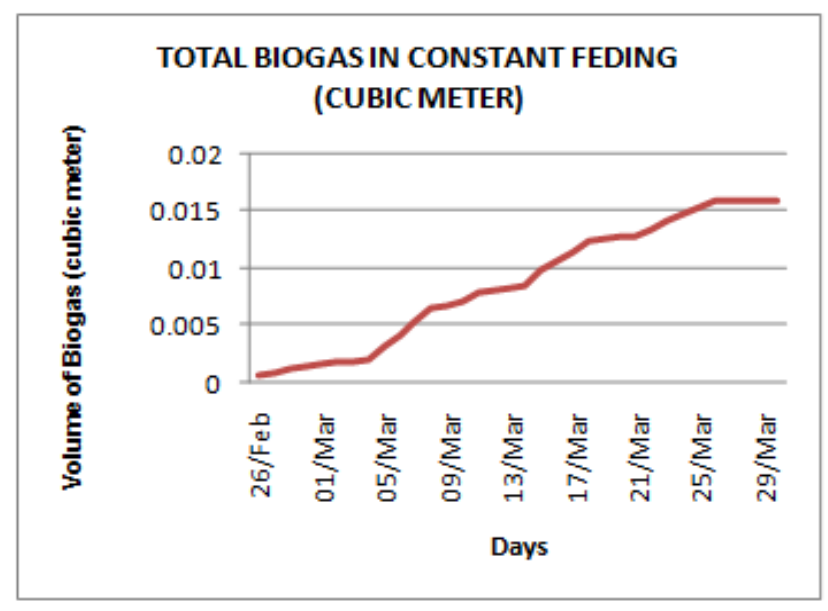

Graph 1 Total Biogas In Constant Feeding (Cubic Meter)

This chamber containing water is used for finding out the amount of gas liberated. The procedure we are using here is water displacement method. The lime solution scrubber is used for the reason that we can only get methane gas which is purely flammable. Application of pressure to the bladder by opening the $\mathrm{T}$ section and closing the digester will lead to displacement of water from the water chamber. The amount of water displaced will give you the amount of methane liberated.

On 11-02-2016 after the installation of the digester, the mixture of cow dung with water was added in following amounts given in table 1

Table 1 Feeding

\begin{tabular}{|l|l|}
\hline $\begin{array}{l}\text { Constant feeding } \\
\text { digester }\end{array}$ & Variable feeding digester \\
\hline $\begin{array}{l}\text { The volume of digester } \\
\text { is 24lts. }\end{array}$ & $\begin{array}{l}\text { The volume of digester is } \\
181 \mathrm{lts} .\end{array}$ \\
\hline $\begin{array}{l}\text { Cow dung used is } 6 \mathrm{~kg} \\
\text { (25\% of volume of } \\
\text { digester) }\end{array}$ & Cow dung used is 5kg. \\
\hline $\begin{array}{l}\text { The water content is } \\
\text { 12lts.ie, } 1: 2 \text { ratios of cow } \\
\text { dung and water. }\end{array}$ & $\begin{array}{l}\text { The water content is 10lts.ie, } \\
\text { water. }\end{array}$ \\
\end{tabular}

After the feeding for a period of 4days the digester was made to wait so that the generation of microbes takes place. Then it was fead same cow dung by $0.2 \%$ the size of the digester.ie, waste (cow dung+ water). From 15-02-2016 till 17-02-2016 cow dung was fed for constant feeding digester by $48 \mathrm{gms}$ and water content of $96 \mathrm{ml}$. Then for the variable feeding digester the cow dung was fed by $36 \mathrm{gms}$ and the water content of $72 \mathrm{ml}$. On 17-02-2016, the flame test was done, but non-flammable gas was obtained for both constant and variable digester. The gas which was collected in the bladder is removed till that date and again continued feeding same cow dung till 23-02-2016. On 24-02-2016, the flame test for the gas which was liberated from the bladder and obtained flammable gas for both variable as well as constant feeding digester.

\section{RESULT AND ANALYSIS}

The results for the above feeding and obtaining of gases from both the variable and constant feeding digesters are calculated from the experimentation which took pace for these many days and their values are noted. This value for constant feeding increases and becomes constant and for the variable feeding increases at first instance and the decreases and the starts varring although for constant feeding the maximum constant value is taken as the gas produced and for variable feeding digester it's the first maximum value of gas produced. These values are shown as per the graphs given below:

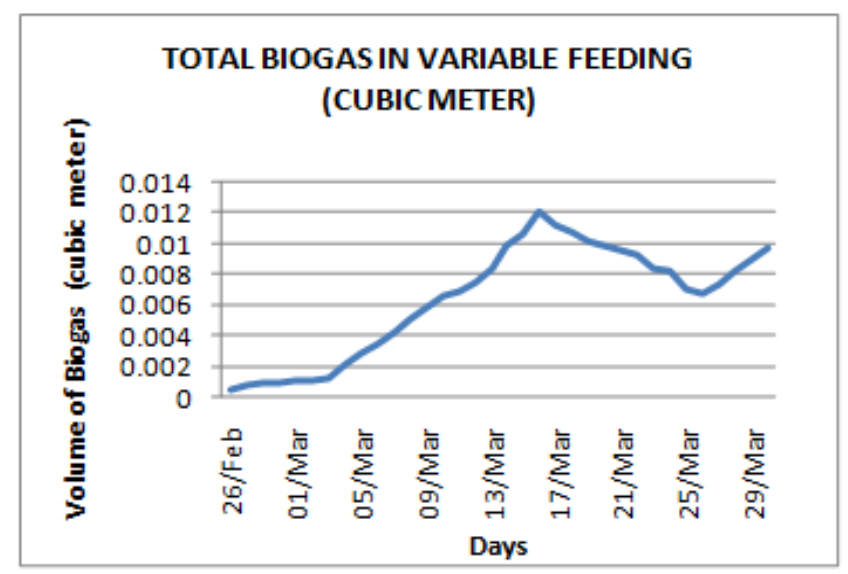

Graph 2 Total biogas In Variable Feeding (Cubic Meter)

\subsection{Result Analysis}

Since it is relied upon to supplant a bit of L P G gas, the imperativeness meet for 1 assembly of LPG is processed. Comparability with the LPG is given as below:

Calorific LPG estimation is $50 \mathrm{MJ} / \mathrm{kg}$

1 chamber weight is $14.2 \mathrm{~kg}$

Thusly, Total vitality in one barrel is 14.2 multiply with 50 The Total vitality in one barrel is equal to $710 \mathrm{MJ}$

The essentialness which would be available in $1 \mathrm{~m} 3$ plant in 1 month. Biogas contains almost about $60 \%$ of methane.

Calorific quantity of the methane gas is $55 \mathrm{MJ} / \mathrm{kg}$

Thickness of $\mathrm{CH} 4$ at the NTP is equal to $0.668 \mathrm{~kg} / \mathrm{cubic}$ meter

Thusly, Calorific estimation of the methane gas is equal to $55 \times 0.668$ is equal to $36.74 \mathrm{MJ} / \mathrm{m}^{3}$

Methane gas being the main real wellspring of warmth,

So Calorific estimation of the biogas is equal to

$0.6 * 36.74 \mathrm{MJ} / \mathrm{m}^{3}=22.044 \mathrm{MJ} /$ cubic meter

According to this project result the constant feeding digester of size 24ltrs produce a maximum $\mathrm{CH}_{4}$ gas of $0.0113 m^{3}$.

Since the $\mathrm{CO}_{2}$ is present in $40 \%$ of total gas, the maximum total amount of biogas liberated by 24ltrs digester is $0.01582 \mathrm{~m}^{3}$

Therefore, $1 \mathrm{~m}^{3}$ of biogas plant produces = $(0.01582 * 1) / 0.024=0.659$

Net vitality in $0.659 \mathrm{~m}^{3}$ of the biogas $=0.659 * 22 \mathrm{MJ}$

Total vitality in $0.659 \mathrm{~m}^{3}$ of the biogas $=14.49 \mathrm{MJ}$

Vitality given every month $=14.49 * 30$ 
Vitality given every month $=434.7 \mathrm{MJ}$

Thusly a plant of biogas of one $\mathrm{m}^{3}$ limit is proportionate to a $61.2 \%$ of a LPG chamber for every month as per our study for constant feeding.

According to this project result the variable feeding digester of size 18ltrs produce a maximum $\mathrm{CH}_{4}$ gas of $0.0086 \mathrm{~m}^{3}$.

Since the $\mathrm{CO}_{2}$ is present in $40 \%$ of total gas, the maximum total amount of biogas liberated by 181trs digester is $0.01204 \mathrm{~m}^{3}$

Therefore, $1 \mathrm{~m}^{3}$ of biogas plant produces = $(0.01204 * 1) / 0.018=0.66$

Net vitality in $0.66 \mathrm{~m}^{3}$ of the biogas $=0.66 * 22 \mathrm{MJ}$

Total vitality in $0.66 \mathrm{~m}^{3}$ of the biogas $=14.5 \mathrm{MJ}$

Vitality given every month $=14.5 * 30$

Vitality given every month $=435 \mathrm{MJ}$

Thusly a plant of biogas of one $\mathrm{m}^{3}$ limit is proportionate to a $61.2 \%$ of a LPG chamber for every month as per our study for constant feeding.

\section{CONCLUSION}

The results obtained for both constant and variable feeding digester are almost same. The actual proportion of $65 \%$ is to be obtained instead of which we get the value of $61.2 \%$ this small error in the proportion is due to the change in temperature, pressure and also the change in the technique of gas measurement. Hence the prototype digester has proved to be a success. Food waste generated in canteens are in large quantities therefore a $10000 \mathrm{~L}$ digester will be sufficient and effective

\section{ACKNOWLEDGEMENT}

Our most sincere and grateful acknowledgements to the holy sanctum of Sahyadri College Of Engineering And Management which enable us to pursue the B.E, Civil Engineering, thus helping us to make a bright career in engineering. We are pleased to express our sincere thanks and deep sense of gratitude Dr. Umesh M Bhushi, Principal of SCEM for providing all the facilities that helped us in the timely completion of this project. Heartfelt thanks to Prof. Umesh S.S,HOD of Civil Department who gave us constant encouragement, advice and guidance in carrying out this project successfully. We are grateful to our guide MsRashmishree K.N,Asst. Prof. for her constant support, frequent guidance and encouragement provided throughout the completion of the project.

\section{REFERENCES}

[1]. Rajendra Beedu ${ }^{1}$ and Pratik Modi ${ }^{2}$, "Design of Bio Gas Generation Plant Based on Food Waste", ${ }^{2}$ Department of Mechanical and Manufacturing Engineering, MIT, Karnataka, India Accepted 10 January 2014, Available online 1 February 2014, Issue-2, (February 2014).

[2]. Dupade Vikrant ${ }^{1}$, Pawar Shekhar ${ }^{2}$,"Generation of Biogas from Kitchen Waste -Experimental Analysis", ${ }^{1}$ Mechanical Engineering Department, VPCOE Baramati/ University of Pune, India, ${ }^{2}$ Mechanical Engineering Department, VPCOE Baramati/ University of Pune, India,International Journal of Engineering Science Invention, October, 2013.

[3]. Ravi P. Agrahari ${ }^{1}$, G. N. Tiwari ${ }^{2}$ "The Production of Biogas Using Kitchen Waste" ${ }^{, 1,2}$ Centre for Energy Studies, IIT Delhi, India, International Journal of Energy Science (IJES) Volume 03 Issue 6, December2013.

[4]. Karthik Rajendran, "Household Biogas Digesters-A Review",Solmaz Aslanzadeh and Mohammad J. Taherzadeh, School of Engineering, University of Borås, Borås 50190, Sweden; Received: 11 May 2012; Accepted: 30 July 2012 and Published- 8 August 2012.

[5]. P.A.Gadge ${ }^{1}$, Dr A.C.Waghmare ${ }^{2}$, V.R. Ninave ${ }^{3}$, "Biogas Generation Plant Based On Kitchen Waste Material", 1 Head of Dept. of Mechanical Engig., V.M.I.T.

Nagpur,INDIA, ${ }^{2}$ PrincipalU.C.O.E.R.,Umrer,INDIA, ${ }^{3} U$ ndergraduateStudent,Dept. of Mechanical Engg., V.M.I.T, INDIA,03 Feb 2014.

[6]. Kobra Salehi, Seyed Masoom Khazraee, Fatemeh Sadat Hoseini, and Farnoush Khosravanipour Mostafazadeh, "Laboratory Biogas Production from Kitchen Wastes and Applying an Adaptive Neuro Fuzzy Inference System as a Prediction Model", International Journal of Environmental Science and Development, Vol. 5, No. 3, June 2014.

[7]. Navjot Riar ${ }^{1}$, Dr. R.K.Khitoliya ${ }^{2}$ And Dr. Shakti Kumar3 "A Study of Treatability of Kitchen Wet Waste And Biogas Production", ' M.E Environmental Engg., Final Year Student, Department Of Civil Engineering PEC University of Technology Chandigarh, ${ }^{2}$ Head Of Department , Post Graduate Department Of Civil Engineering, PEC , University of Technology Chandigarh , ${ }^{3}$ Associate Professor, Post Graduate Department Of Civil Engineering, PEC, University of Technology Chandigarh India, International Journal of Computational Engineering Research, Volume03,Issue-6, 2014.

[8]. R. K. Somashekar ${ }^{1}$, Rinku Verma ${ }^{2}$, Manzoor Ahamd $\mathrm{Naik}^{3}$,"Potential of biogas production from food waste in a uniquely designed reactor under lab conditions", ${ }^{1}$ Department of Environmental Science, Bangalore University, Jnana Bharathi Campus,Bangalore, Karnataka, 560056, India, ${ }^{2}$ Department of Farm Forestry \& Environmental Science, University of Agricultural Sciences, Bangalore, College of Sericulture, Chintamani 563125, Karnataka, India , Department of Ecology, French Institute of Pondicherry,11, Saint Louis St, Pondicherry,605001, India,International Journal of Geology, Agriculture and Environmental SciencesVolume - 02 Issue - 02 April 2014.

[9]. Ziana Ziauddin1, Rajesh P2, "Potential of biogas production from food waste in a uniquely designed reactor under lab conditions", 1M.Tech , Energy Systems, Department of EEE, Nehru College of Engineering And Research Centre, Kerala, India 2 Assistant Professor, Dept. of EEE, Nehru College of Engineering And Research Centre, Kerala, India,International Research Journal of Engineering and Technology (IRJET) Vol-02, Issue-04,July-2015. 
[10].K.M.Akkoli1, B.M.Dodamani2, Jagadeesh A3, Ravi C4, "Design and Construction of food waste biogas plant for hostel mess", Dept. Of Mechanical Engineering, Hirasugar Institute of Technology, Nidasoshi, Karnataka, India, International Journal for Scientific Research \& Development (IJSRD) Vol 3, Issue $03,2015$.

\section{BIOGRAPHIES}

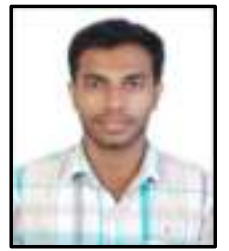

Blesson $\mathbf{S}$ was born in Delhi, India in 1994. He received his BE degree in civil from Sahyadri college of Engineering \& Management institution, under Visvesvaraya Technological University, Belgaum, India

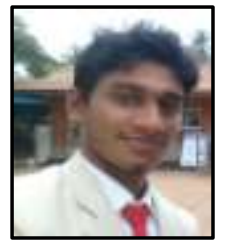

Ashish Ashok was born in Kerala, India in 1994. . He received his BE degree in civil from Sahyadri college of Engineering \& Management institution, under Visvesvaraya Technological University, Belgaum, India

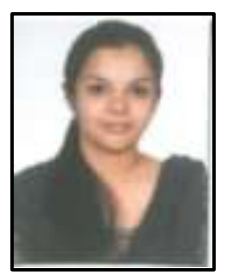

Arha Raghavan was born in Thalassery, Kerala, India in 1993. She received her BE degree in civil from Sahyadri college of Engineering \& Management institution, under Visvesvaraya Technological University, Belgaum, India. Now she is Business Development Executive at InterCAD System P.Ltd Trivandrum Branch.

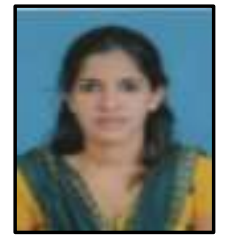

Divya $\mathbf{P}$ Gunagi was born in karwar, Karnataka, India, in 1992. She received her BE degree in civil from Sahyadri college of Engineering \& Management institution, under Visvesvaraya Technological University, Belgaum, India

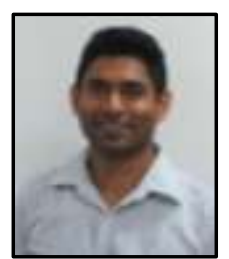

Dr. Gautham Jeppu was born in Mulky, Karnataka. He obtained his Bachelor's degree from NITK, Surathkal in Chemical Engineering and Masters and $\mathrm{PhD}$ in Environmental engineering from Auburn University, USA. His research interests are in field of environmental engineering, drinking water and biogas.

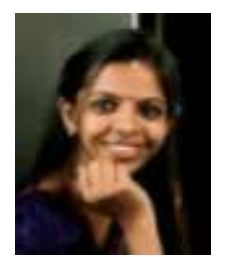

Ms. Rashmishree KN was born in sullia, D.K. Karnataka. Obtained her bachelor degree from KVGCE Sullia and Masters from NITK Surathkal. Research interests are in the field of water and waste water treatment 